\title{
Use of stabilized thaw slumps by Arctic birds and mammals: evidence from Herschel Island, Yukon
}

\author{
Heather A. Cray ${ }^{1, *}$ and Wayne H. Pollard ${ }^{2}$ \\ ${ }^{1}$ University of Waterloo, School of Environment, Resources, and Sustainability, Environment 2, 200 University Avenue West, \\ Waterloo, Ontario N2L 3G1 Canada \\ ${ }^{2}$ McGill University, 805 Sherbrooke Street West, Montréal, Quebec H3A 0B9 Canada \\ ${ }^{*}$ Corresponding author: hcray@uwaterloo.ca
}

Cray, H.A., and W.H. Pollard. 2018. Use of stabilized thaw slumps by Arctic birds and mammals: evidence from Herschel Island, Yukon. Canadian Field-Naturalist 132(3): 279-284. https://doi.org/10.22621/cfn.v132i3.1988

\begin{abstract}
As evidenced by animal sign (scat, active nests, nesting materials, rodent runways) observed across five stabilized retrogressive thaw slumps and two areas of undisturbed upland tundra, Arctic birds and mammals on Herschel Island, Canada, use stabilized thaw slumps differently than undisturbed tundra. Rodent winter nests and scat were found exclusively in undisturbed tundra and at a 250-year-old stabilized thaw slump site, whereas rodent runways and Semipalmated Plover (Charadrius semipalmatus) nests were found exclusively at 10- and 20-year-old stabilized thaw slump sites. Bird scat was found in each tundra type, but was most common in the youngest sites, and the number of observations decreased with increasing site age. Caribou (Rangifer tarandus granti) scat was found at all sites, whereas Muskox (Ovibos moschatus) scat was not found at 20-year-old sites and was most common in undisturbed tundra. To our knowledge, these observations are the first examples of birds and mammals using stabilized thaw slump habitat of different ages, and they provide new avenues of research for Arctic wildlife biologists concerned with the adaptation of these animals to permafrost disturbance and the resulting changes in vegetation cover.
\end{abstract}

Key words: Arctic; wildlife; thaw slump; Herschel Island; disturbance

\section{Introduction}

Retrogressive thaw slumps are among the most widespread thermokarst forms in the western Arctic, and each slump changes the physical and biotic characteristics of hectares of land (Mackay 1963; Cray and Pollard 2015). On Herschel Island, Yukon, Canada $\left(69^{\circ} 36^{\prime} \mathrm{N}, 139^{\circ} 04^{\prime} \mathrm{W}\right.$, an area of $\left.108 \mathrm{~km}^{2}\right)$, there are over 100 active thaw slumps, and, since the 1950 s, thaw slumps in the western Arctic have been increasing in both area and number (Lantuit and Pollard 2008; Lantz and Kokelj 2008). Permafrost disturbances and related changes in flora may affect the spatial extent of fauna disproportionately by creating habitat heterogeneity that may alter how animals use the landscape (Forbes et al. 2001). By creating numerous large, discrete disturbances with distinct vegetation communities caused by the different age classes of the stabilized slumps (Cray and Pollard 2015), retrogressive thaw slumping and the associated stages of revegetation alter the tundra landscape; as the incidence and extent of these slumps increase, it becomes increasingly important to assess the potential consequences for wildlife.

\section{Study Area}

Part of the Yukon Coastal Plain, Herschel Island's mosaic of terrestrial, wetland, and littoral habitats is visited by diverse populations of migrating and nesting waterfowl, passerines, shorebirds, and raptors, as well as Porcupine Caribou (Rangifer tarandus granti) and Muskox (Ovibos moschatus). Of the 121 bird species recorded on Herschel Island, 46 use it as a breeding site
(Yukon Bird Club 2015). The island is especially important as breeding habitat, as numerous Arctic-breeding species, particularly shorebirds, are in dramatic population decline (Gratto-Trevor et al. 2011). The four common small mammals recorded there are Northern Collared Lemming (Dicrostonyx groenlandicus), Brown Lemming (Lemmus trimucronatus), Tundra Vole (Microtus oeconomus), and Arctic Ground Squirrel (Spermophilus parryii; Krebs et al. 2011, 2012). These species are a fundamental part of the Arctic food web, as they are a food source for various avian and mammalian predators (Krebs et al. 2012). Small portions of the Porcupine Caribou herd spend time on Herschel Island, particularly from late April through August, with herds ranging in size from 21 to 75 individuals including bulls, cows, calves, and yearlings; in some years, Caribou have also been observed calving on the island (Cooley et al. 2012).

\section{Methods}

We recorded animal sign (scat, nests, rodent runways) in July 2011 from a total of $5791 \mathrm{~m} \times 1$ m quadrats (Table 1) used in a vegetation community development study on slump stabilization (see Cray and Pollard 2015). Study sites on Herschel Island (Figure 1) included two stable upland tundra areas and five stabilized retrogressive thaw slumps representing three age classes: 10 years (two sites), 20 years (two sites), and 250 years (one site) since stabilization. For the 10- and 20-yearold stabilized thaw slumps, the year of stabilization was established by identifying the season in which there was

A contribution towards the cost of this publication has been provided by the Thomas Manning Memorial Fund of the Ottawa Field-Naturalists' Club. 


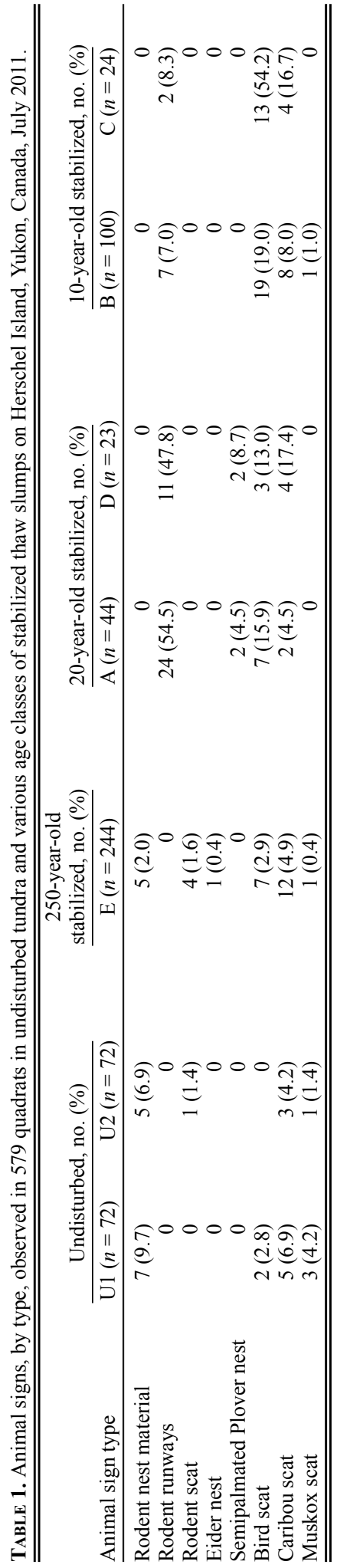

no further headwall exposure or melt; the 250-year-old stabilized site was dated through sedimentological, geochemical, and accelerator mass spectrometry radiocarbon dating analyses by Lantuit et al. (2012).

Any recognizable scat was recorded; therefore, our observations likely consider droppings from multiple years. The number of quadrats sampled for each study site was scaled to $1 \%$ of the total area of each stabilized retrogressive thaw slump; $80 \%$ of these quadrats were spaced evenly along a transect perpendicular to the stabilized headwall, and the remaining $20 \%$ were distributed randomly within the stabilized area (for additional details see Cray and Pollard 2015). To maintain sampling uniformity, undisturbed areas were sampled with both transects and random quadrats in the same way as the other sites, where the median number of sample quadrats and the mean transect length were used for both undisturbed areas and the boundaries were assigned as a rectangle surrounding the transect (Figure 1).

\section{Results}

Rodent scat was observed only in the 250-year-old and undisturbed sites, whereas Caribou scat was observed in small amounts at every site (Table 1). Muskox scat was observed most frequently in the undisturbed sites and was not observed in the 20 -year-old stabilized sites. Piles of dried grass and sedge material from rodent winter nests, $15-20 \mathrm{~cm}$ in diameter, likely representing complete nests (Krebs et al. 2012), were recorded at both the undisturbed and 250-year-old sites, although they were more frequent in undisturbed tundra. Nesting materials at the 250 -year-old site were most frequently located near the headwall of the stabilized thaw slump. Surface grass tunnels, often referred to as runways (Krebs et al. 2012), were observed at the four 10- and 20 -year-old stabilized slumps and were most common in the 20-year-old stabilized thaw slumps.

Although bird droppings were observed at every age class of tundra in this study, they were most frequent at the 10-year-old sites and decreased as site age increased. Of the five active bird nests we recorded, one was a Common Eider (Somateria mollissima) in the centre of the 250-year-old site and four were Semipalmated Plover (Charadrius semipalmatus) located in the approximate centre of the 20-year-old slump floors.

During the active period of a thaw slump and in the first few years following stabilization, animal tracks are readily observable in the soft mud of the slump floor (H.A.C. pers. obs.). Although not particularly useful for comparison between slump age classes, Muskox, Sandhill Crane (Grus canadensis), and Caribou tracks were also common in the slump floors of both 10 - and 20-year-old sites.

\section{Discussion}

Based on our observations of animal signs, tundra birds and mammals appear to use stabilized slump surfaces and undisturbed tundra differently. Although our observations are limited to a small area and only one 


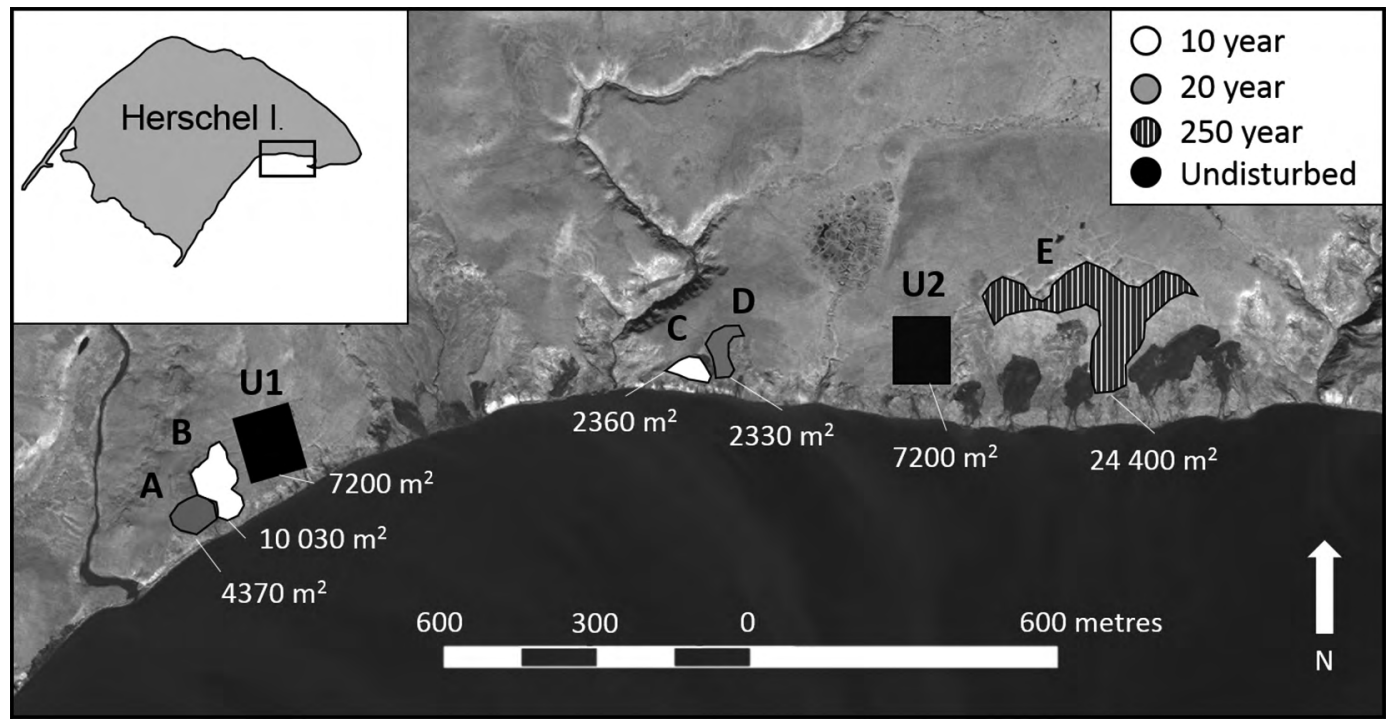

FigurE 1. Locations of the seven study sites on Herschel Island, Yukon, Canada, including areas and age class of stabilized thaw slumps.

field season, these differences in rodent and bird habitat choice may be of interest to wildlife biologists for future study.

The occurrence of rodent burrows and winter nests near the headwall of the 250 -year-old site could be because of the residual concave and steep morphology of long-stabilized thaw slumps, which leads to greater snow accumulation and, thus, thermal insulation for lemmings (Reid and Krebs 1996; Lantz et al. 2009; le Roux et al. 2011; Reid et al. 2011). As no rodent winter nesting materials were observed at the stabilized thaw slump sites, we suspect that the deposited dry, flat microtopography of the 10- and 20-year-old slumps is not preferred as winter nest sites. As all stabilized sites studied and many of the other more than 100 active and stabilized thaw slumps on Herschel Island are located in smooth or sloping uplands previously characterized by Arctic Willow/Dryas-vetch or cottongrass/moss vegetation type (Smith et al. 1989; Lantuit and Pollard 2008; Lantz and Kokelj 2008; Cray 2010, 2012), which is good year-round lemming habitat (Ale et al. 2011), the lack of burrows, rodent scat, or old nesting material at the 10- and 20-year-old sites suggests that an increase in the number and density of new thaw slumps may negatively impact rodent nesting habitat in the short term. However, rodent runways through the tall grasses were observed at all of the 10 - and 20 -year-old sites. In each area where there was a large percentage cover and height of grasses (i.e., $50 \%$ or more of the plant cover was $>15 \mathrm{~cm}$ high), rodent runways were observed (Figure 2). Although no burrows or winter nests were found, rodents are likely making regular use of the 10- and 20-year-old sites as evidenced by the consistently trampled runways. Specific uses likely vary by species and may include foraging for graminoids and seeds and collecting nesting material.

On Herschel Island, Collared Lemmings have been shown to select dry habitat dominated by Entire-leaved Mountain Avens (Dryas integrifolia Vahl; Ale et al. 2011) and to have a diet of mainly willow (Salix spp. L.), D. integrifolia, and Mountain Cranberry (Vaccinium vitis-idaea L.; Batzii and Jung 1980; Rodgers and Lewis 1986). Although D. integrifolia is most prevalent in the undisturbed tundra sites (present at $92 \%$ of sites, average cover 9\%), it is also present at the 250year-old site (present at $43 \%$ of sites, average cover $3 \%$; Cray 2012), and various species of Salix are common at all sites studied (Cray 2012), particularly Arctic Willow (Salix arctica Pallas), which is highly preferred by Collared Lemmings (Rodgers and Lewis 1986).

Brown Lemmings may also benefit from foraging in the vegetation community that establishes following thaw slump stabilization. Although Brown Lemming has a pronounced preference for wet meadow habitat, compared with Tundra Vole and Collared Lemming, it is a habitat generalist (Batzli and Lesieutre 1995; Ale et al. 2011) whose diet is dominated by monocots, particularly sedges such as Water Sedge (Carex aquatilis Wahlenberg) and cottongrass (Eriophorum spp. L.) as well as mosses (Batzli and Jung 1980). Although too dry to support $C$. aquatilis and too recently disturbed to have established Eriophorum, the stabilized thaw slump sites do support both higher frequencies and a higher percentage cover of mosses than undisturbed tundra (Cray 2012), and the graminoid-rich communities of 10 - and 20 -year-old sites likely provide suitable forage for Brown Lemmings. 
a

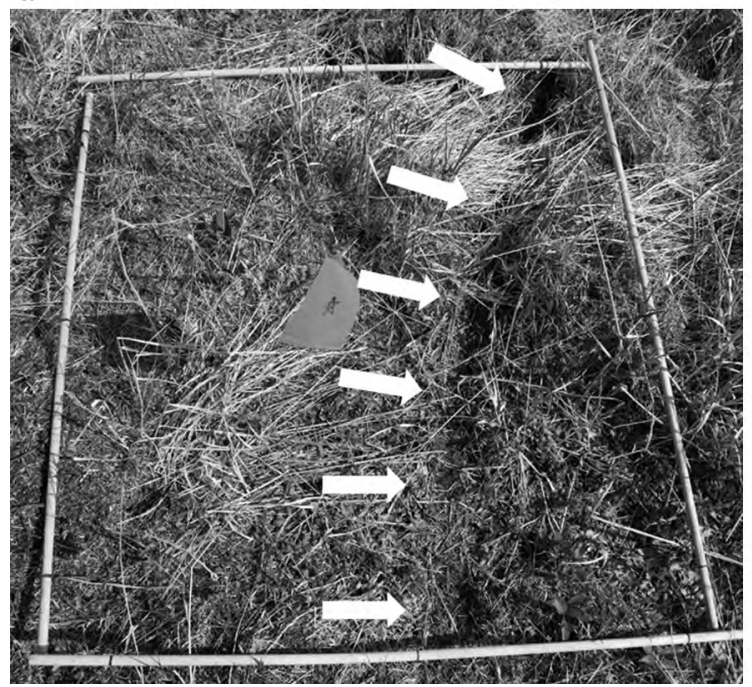

b

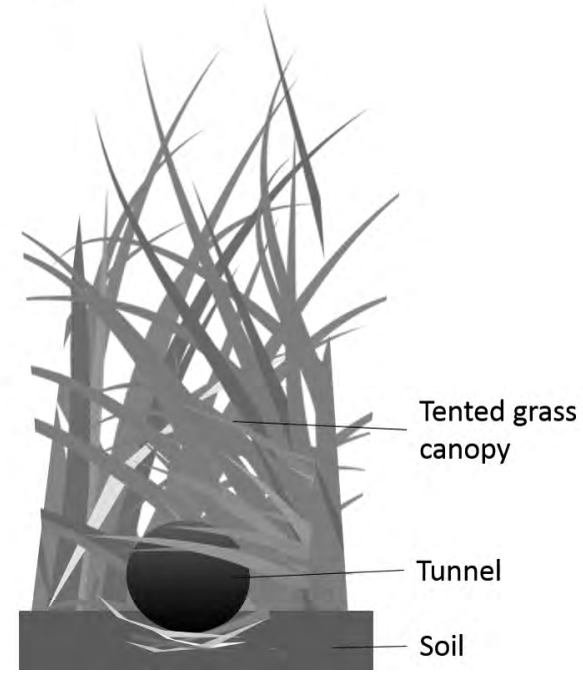

FigURE 2. a. Photo of a quadrat in the 20 -year-old stabilized thaw slump age class showing rodent surface grass tunnelling (runways). b. Lateral view of rodent runways through grass; note the tented canopy of grass obscuring the overhead view and the slight depression into the soil surface from repeated use. Photo and illustration: Heather Cray.

In contrast, although Tundra Voles have been shown to have a flexible diet including a variety of grasses, sedges, and forbs (e.g., lousewort [Pedicularis L.]) typical of the stabilized thaw slumps (Batzli and Jung 1980; Cray and Pollard 2015), this species is rarely found outside Pauline Cove, $3 \mathrm{~km}$ away from the study sites (Krebs et al. 2012); on Herschel Island, it has been shown to prefer very wet habitat dominated by Eriophorum spp., Carex spp., and Salix spp. (Ale et al. 2011), more characteristic of undisturbed tundra. Therefore, it is unlikely that Tundra Voles are responsible for the animal sign found in stabilized slumps.

Tundra bird species also use stabilized thaw slump floors, certainly as nesting sites which were directly observed, and possibly as foraging areas as well. As the quadrat method we used is not ideal for observing bird nests and observations were made during only one field season, our nest observations likely underrepresent the true use of these stabilized surfaces by bird species. Also, as we did not identify bird scat to species, it is difficult to determine potential preferences of specific birds for certain cover types or vegetation communities. Because distinct vegetation communities were found to be associated with each age of stabilized thaw slump in the study by Cray and Pollard (2015), forage opportunities (arthropods, seeds) and nesting habitat would be expected to differ as well.

For Semipalmated Plover, which prefer to nest in an open area with little to no plant growth, disturbed patches may actually increase their breeding habitat, which otherwise mainly consists of beaches or open pebbled areas (Nguyen et al. 2003). Indeed, the Semipalmated Plover is among the few plovers whose numbers in- creased between 1974 and 2009 and are currently stable (Andres et al. 2012), perhaps owing to its versatility in food choice or habitat expansion in the low Arctic as a result of disturbance (Nol and Blanken 2014).

Caribou scat was observed at every study site, suggesting that Caribou are at least travelling over if not grazing in every slump age class. Although the resilience of Caribou to vegetation change is contentious (Gunn and Skogland 1997; Callaghan et al. 1998; IPCC 2007), productivity of Caribou populations is strongly related to the quality and abundance of forage (Lenart et al. 2002) and the Porcupine Caribou Herd is known to forage extensively in the Tussock Grass (Eriophorum vaginatum $\mathrm{L}$.) meadow community (cottongrass/moss) in the pre-calving and calving periods when Eriophorum heads are some of the first fresh vegetation available with significant biomass, cell solubles, nitrogen, and phosphorus (Russell et al. 1993). Although the cottongrass/moss vegetation type is generally considered stable (Smith et al. 1989), four of the five stabilized sites studied were located in this vegetation community, where thaw slumping initiated by coastal erosion progressed inland. Because Eriophorum does not recolonize stabilized thaw slumps even after 250 years (Cray and Pollard 2015), the significant increase in permafrost degradation expected with further climate change (Maxwell 1997) may affect the local availability of this vegetation type on Herschel Island and other upland areas prone to thaw slump activity, particularly areas adjacent to coastlines, lakes, and rivers.

Reductions in upland vegetation communities may also affect Muskox. The diet of Muskox consists mainly of graminoids, particularly sedges (e.g., Carex spp. and 
Eriophorum spp.) and willows (Salix spp.; Ihl and Klein 2001; Larter and Nagy 2004), which are characteristic of undisturbed tundra sites on Herschel Island. Although stabilized thaw slumps are colonized by graminoid species within a few decades, the relative paucity of sedge and willow species at these sites (Cray and Pollard 2015) may explain the scarcity of Muskox scat observed at stabilized thaw slumps. With respect to winter forage, the increased snow accumulation within thaw slumps may also limit the availability of this food source for overwintering herds (Ihl and Klein 2001; Gustine et al. 2011).

Although our study indicates that mammals and birds appear to use recently stabilized thaw slumps, further investigation would be required to account for the complex biotic interactions and to predict consequences of the future, widespread permafrost disturbances expected with climate warming. As thaw slumps are expected to continue to increase in both area and number, the altered wildlife use associated with them present an interesting avenue for future research, particularly as the morphology, soil conditions, and vegetation community of stabilized slumps remain distinct from undisturbed tundra for over 250 years. To our knowledge, these observations are the first examples of birds and mammals using stabilized thaw slump habitat of different ages. We encourage all researchers working in these systems to record and report supplementary wildlife observations, as these observations play a useful role in building the larger wildlife and ecosystem knowledge base. Last, we suggest that long-term wildlife monitoring of stabilized thaw slumps would shed light on Arctic species' ability to adapt to permafrost disturbance and the resulting changes in vegetation cover.

\section{Author Contributions}

Writing - Original Draft: H.C.; Writing - Review \& Editing: H.C. and W.P.; Conceptualization: H.C.; Investigation: H.C.; Methodology: H.C.; Formal Analysis: H.C.; Funding Acquisition: W.P. and H.C.

\section{Acknowledgements}

We thank the Natural Sciences and Engineering Research Council of Canada, the Polar Continental Shelf Program, the Northern Scientific Training Program, and ArcticNet for their financial support. We also appreciate the editorial contributions of Editor-in-Chief Dr. Dwayne Lepitzki, Associate Editor Dr. Bill Halliday, reviewer Don Reid, and two anonymous reviewers.

\section{Literature Cited}

Ale, S.B., D.W. Morris, A. Dupuch, and D.E. Moore. 2011. Habitat selection and the scale of ghostly coexistence among Arctic rodents. Oikos 120: 1191-1200. https://doi. org/10.1111/j.1600-0706.2010.18933.x

Andres, B.A., P.A. Smith, R.I.G. Morrison, C.L. GrattoTrevor, S.C. Brown, and C.A. Friis. 2012. Population estimates of North American shorebirds, 2012. Wader Study
Group Bulletin 119: 178-194. Accessed 16 August 2017. http://www.waderstudygroup.org/article/1967.

Batzli, G.O., and H.G. Jung. 1980. Nutritional ecology of microtine rodents: resource utilization near Atkasook, Alaska. Arctic and Alpine Research 12: 483-499. https://doi.org/ $10.2307 / 1550496$

Batzli G.O., and C. Lesieutre. 1995. Community organization of arvicoline rodents in northern Alaska. Oikos 72: 88-98. https://doi.org/10.2307/3546042

Callaghan, T.V., C. Körner, S.E. Lee, and J.H.C. Cornelison. 1998. Part 1: scenarios for ecosystem responses to global change. Pages 11-63 in Global Change in Europe's Cold Regions. Edited by O.W. Heal, T.V. Callaghan, J.H.C. Cornelissen, C. Körner, and S.E. Lee. Ecosystems research report 27. European Commission, Luxembourg.

Cooley, D., C.D. Eckert, and R.R. Gordon. 2012. Herschel Island-Qikiqtaruk inventory, monitoring, and research program. Yukon Parks, Whitehorse, Yukon, Canada.

Cray, H.A. 2010. A characterization of the vegetation communities of three retrogressive thaw slumps on Herschel Island, Yukon Territory, Canada. B.Sc. thesis, McGill University, Montréal, Quebec, Canada.

Cray, H.A. 2012. A characterization of vegetation succession patterns related to retrogressive thaw slumps on Herschel Island, Yukon Territory, Canada. M.Sc. thesis, McGill University, Montréal, Quebec, Canada.

Cray, H.A., and W.H. Pollard. 2015. Vegetation recovery patterns following permafrost disturbance in a low Arctic setting: case study of Herschel Island, Yukon, Canada. Arctic, Antarctic, and Alpine Research 47: 99-113. https://doi. org/10.1657/AAAR0013-076

Forbes, B.C., J.J. Ebersole, and B. Strandberg. 2001. Anthropogenic disturbance and patch dynamics in circumpolar arctic ecosystems. Conservation Biology 15: 954-969. https://doi.org/10.1046/j.1523-1739.2001.015004954.x

Gratto-Trevor, C., R.I.G. Morrison, B. Collins, J. Rausch, M. Drever, and V. Johnston. 2011. Trends in Canadian shorebirds. Canadian biodiversity: ecosystem status and trends 2010, technical thematic report 13. Canadian Councils of Resource Ministers, Ottawa, Ontario, Canada. Accessed 16 August 2017. http://www.biodivcanada.ca/defa ult.asp?lang=En\&n=A344C5AE-1\&printfullpage=true.

Gunn, A., and T. Skogland. 1997. Responses of caribou and reindeer to global warming. Ecological Studies 124: 189200. https://doi.org/10.1007/978-1-4612-2240-8_10

Gustine, D.D., P.S. Barboza, J.P. Lawler, S.M. Arthur, B.S. Shults, K. Persons, and L.G. Adams. 2011. Characteristics of foraging sites and protein status in wintering muskoxen: insights from isotopes of nitrogen. Oikos 120: 1546-1556. https://doi.org/10.1111/j.1600-0706.2011.19215.x

Ihl, C., and D.R. Klein. 2001. Habitat and diet selection by muskoxen and reindeer in western Alaska. Journal of Wildlife Management 65: 964-972.

IPCC (Intergovernmental Panel on Climate Change). 2007. Climate change 2007: synthesis report. Contribution of working groups I, II and III to the fourth assessment report of the intergovernmental panel on climate change. Edited by Core Writing Team, R.K. Pachauri, and A. Reisinger. IPCC, Geneva, Switzerland. Accessed 21 December 2018. https:// www.ipcc.ch/report/ar4/syr/.

Krebs, C.J., D. Reid, S. Gilbert, and A.J. Kennedy. 2012. Small mammals. Pages 107-111 in Herschel Island Qikiqtaryuk: A Natural and Cultural History of Yukon's Arctic Island. Edited by C.R. Burn. University of Calgary Press, Calgary, Alberta, Canada. 
Krebs, C.J., D. Reid, A. Kennedy, and S. Gilbert. 2011. Fluctuations in lemming populations in north Yukon, Canada, 2007-2010. Canadian Journal of Zoology 89: 297-306. https://doi.org/10.1139/z11-004

Lantuit, H., and W.H. Pollard. 2008. Fifty years of coastal erosion and retrogressive thaw slump activity on Herschel Island, southern Beaufort Sea, Yukon Territory, Canada. Geomorphology 95: 84-102. https://doi.org/10.1016/j.geo morph.2006.07.040

Lantuit, H., W.H. Pollard, N. Couture, M. Fritz, L. Schirrmeister, H. Meyer, and H.W. Hubberten. 2012. Modern and late Holocene retrogressive thaw slump activity on the Yukon Coastal Plain and Herschel Island, Yukon Territory, Canada. Permafrost and Periglacial Processes 23: 39-51. https://doi.org/10.1002/ppp.1731

Lantz, T.C., and S.V. Kokelj. 2008. Increasing rates of retrogressive thaw slump activity in the Mackenzie Delta region, N.W.T., Canada. Geophysical Research Letters 35: L06502. https://doi.org/10.1029/2007GL032433

Lantz, T.C., S.V. Kokelj, S.E. Gergel, and G.H.R. Henry. 2009. Relative impacts of disturbance and temperature: persistent changes in microenvironment and vegetation in retrogressive thaw slumps. Global Change Biology 15: 1664-1675. https://doi.org/10.1111/j.1365-2486.2009.01 917.x

Larter, N.C., and J.A. Nagy. 2004. Seasonal changes in the composition of the diets of Peary caribou and muskoxen on Banks Island. Polar Research 23: 131-140. https://doi.org /10.3402/polar.v23i2.6274

Lenart, E.A., R.T. Bowyer, J. Ver Hoef, and R.W. Ruess. 2002. Climate change and caribou: effects of summer weather on forage. Canadian Journal of Zoology 80: 664-678. https://doi.org/10.1139/z02-034

le Roux, P.C., J. Boelhouwers, J.K. Davis, N.S. Haussmann, E.J. Jantze, and K.I. Meiklejohn. 2011. Spatial association of lemming burrows with landforms in the Swedish subarctic mountains: implications for periglacial feature stability. Arctic, Antarctic, and Alpine Research 43: 223-228. https:// doi.org/10.1657/1938-4246-43.2.223

Mackay, J.R. 1963. The Mackenzie Delta area, N.W.T. Geographical Branch memoir 8. Department of Mines and Technical Surveys, Ottawa, Ontario, Canada.
Maxwell, B. 1997. Responding to Global Climate Change in Canada's Arctic: Volume II of the Canada Country Study: Climate Impacts and Adaptation. Environment Canada, Downsview, Ontario, Canada.

Nguyen, L.P., E. Nol, and F. Abraham. 2003. Nest success and habitat selection of the Semipalmated Plover on Akimiski Island, Nunavut. Wilson Bulletin 124: 285-291. https:// doi.org/10.1676/03-044

Nol, E., and M.S. Blanken. 2014. Semipalmated Plover (Charadrius semipalmatus). In The Birds of North America. Edited by P.G. Rodewald. Cornell Laboratory of Ornithology, Ithaca, New York, USA. Accessed 6 January 2018. http:// bna.birds.cornell.edu/bna/species/444.

Reid, D.G., F. Bilodeau, C.J. Krebs, G. Gauthier, A.J. Kennedy, B.S. Gilbert, M.C.-Y. Leung, D. Duchesne, and E. Hofer. 2011. Lemming winter habitat choice: a snow-fencing experiment. Oecologia 168: 935-946. http://doi.org/ 10.1007/s00442-011-2167-x

Reid, D.G., and C.J. Krebs. 1996. Limitations to collared lemming population growth in winter. Canadian Journal of Zoology 74: 1284-1291. https://doi.org/10.1139/z96-143

Rodgers, A.R., and M.C. Lewis. 1986. Diet selection in Arctic lemmings (Lemmus sibiricus and Dicrostonyx groenlandicus): demography, home range and habitat use. Canadian Journal of Zoology 64: 2717-2727. https://doi.org/10.1139/ z86-396

Russell, D.E., A.M. Martell, and W.A.C. Nixon. 1993. Range ecology of the porcupine caribou herd in Canada. Rangifer 13 (special issue 8): 1-68. https://doi.org/10.7557/2.13. 5.1057

Smith, C.A.S., C.E. Kennedy, A.E. Hargrave, and K.M. McKenna. 1989. Soil and vegetation of Herschel Island. Yukon soil survey report 1. Land Resource Research Centre, Agriculture Canada, Ottawa, Ontario, Canada. Accessed 17 August 2016. http://sis.agr.gc.ca/cansis/publications/sur veys/yt/yt15/index.html.

Yukon Bird Club. 2015. Checklist of the birds of Herschel Island-Qikiqtaruk Territorial Park, April 2015. Yukon Bird Club, Whitehorse, Yukon, Canada. Accessed 10 August 2017. http://www.env.gov.yk.ca/publications-maps/docume nts/Herschel-bird-checklist-2015.pdf.

Received 22 August 2017

Accepted 12 October 2018 